\title{
Modeling the Depositional Environment of the Sandstone Reservoir in the Middle Miocene Sidri Member, Badri Field, Gulf of Suez Basin, Egypt: Integration of Gamma-Ray Log Patterns and Petrographic Characteristics of Lithology
}

\author{
Ahmed E. Radwan $10,2,3$
}

Received 1 July 2020; accepted 21 September 2020

Published online: 1 October 2020

Understanding the depositional setting of siliciclastics reservoir is fundamental process to exploration and development of hydrocarbon reservoirs and to the multi-phase cycle of the oil and gas industry. Typically, core samples from existing or potential reservoirs can be used for interpretation of depositional environment. However, the lack of core samples in certain reservoirs represents a challenge for reservoir development plans and further exploration. To overcome the absence of core samples in the middle Miocene Sidri Member in the Badri field, Gulf of Suez, this study aimed to reconstruct its depositional settings by coupling well logging patterns and petrographic characterization of ditch cuttings. Consequently, 30 thin section samples representing the reservoir section of four wells were described in detail and standard petrographic characteristics were determined. Then, gamma-ray (GR) log patterns of the studied reservoir wells were used for interpretation of depositional environment. Petrographic analysis indicates that the sandstone reservoir is fine- to medium-grained arkose with dominant siliceous cement and composed mainly of quartz, feldspars, and lithic fragments. Pores reflecting primary and secondary porosity as well as inter-granular pores are dominant. The facies analysis indicates that the studied member has a heterogeneous nature and rapid facies change; its main lithofacies are blocky sandstones, intercalated sandstones and shales, and shales. Three electrofacies were interpreted in the studied section: (1) electrofacies-A (blocky sandstones), which is characterized by a cylindrical-shaped (right boxcar) GR trend; (2) electrofacies-B (intercalated sandstones and shales), which is characterized by an irregular log trend with serrated shape; and (3) electrofacies-C (shales), which is characterized by irregular GR trend and has no character. The interpreted results indicate a tidal channel depositional setting for electrofacies-A, mixed tidal flat depositional setting for electrofacies-B, and low relief offshore mudstone depositional setting for electrofacies-C. Finally, the results illustrate how the coupling of GR patterns with the analysis of petrographic characteristics can be used to understand the depositional setting of a hydrocarbon reservoir that lacks core samples. This work could be useful for assessment of reservoir distribution and quality, for reduction of uncertainty during field development, as well as for providing useful insight to similar hydrocarbon reservoirs elsewhere.

${ }^{1}$ Faculty of Geography and Geology, Institute of Geological Sciences, Jagiellonian University, Gronostajowa 3a, 30-387 Kraków, Poland.

${ }^{2}$ Exploration Department, Gulf of Suez Petroleum Company (GUPCO), Cairo, Egypt.

${ }^{3}$ To whom correspondence should be addressed; e-mail: radwanae@yahoo.com 
KEY WORDS: Lithofacies, Gamma-ray pattern, Middle Miocene Sidri Member, Petrographic analysis, Electrofacies, Sandstone reservoir, Gulf of Suez.

\section{INTRODUCTION}

Determination of depositional facies is essential in the oil and gas industry. It can be used for reservoir architecture modeling and for understanding and prediction of facies distribution for field development and exploration stages. Paleoenvironment determination and facies analysis are based mainly on descriptions of core samples in terms of grain size distribution, sedimentary structure, textural features, and mineralogical composition of specific outcrops or subsurface sections. Core samples are mandatory for facies analysis and for understanding sandstone reservoir geometry, architecture, and reservoir quality, which play crucial roles in any hydrocarbon field development and exploitation (Attia et al. 2015; Radwan et al. 2020a). However, core samples are not always available from subsurface sections. Therefore, many researchers refer to gamma-ray (GR) patterns as a possible solution to support interpretation of depositional environments. GR logs have been used globally to interpret the paleo-environment in the absence of core samples (e.g., Kessler and Sachs 1995; Saggaf and Nebrija 1999; Donselaar and Schmidt 2005; Chow et al. 2005; Farrell et al. 2013). The different curve shapes are related to water depth, sediment provenance, and associated hydrodynamic force conditions (Selley 1978; Boggs 1995; Ellis and Singer 2007).

The Badri oil and gas field is one of the significant producing areas, in which middle Miocene clastics act as the primary reservoir (EGPC 1996). The study area is located in the offshore area of the basin, near the Sinai Peninsula shoreline (Fig. 1). The Badri oil and gas field was discovered in 1982 by GS315-1 well, which consisted of a 30-m-thick oilbearing sandstone zone in the Hammam Faraun Member (Belayim Formation), a 45-m-thick gasbearing sandstone, and a 23-m-thick oil-bearing sandstone in the Kareem Formation (EGPC 1996). However, the lack of core samples from the middle Miocene (Serravallian) Sidri sandstone reservoir poses a challenge in the Badri region, especially because this sequence is heterogeneous in terms of lithofacies and it exhibits rapid facies changes.
Therefore, characteristics of ditch cutting and GR patterns were incorporated in this study to compensate for the lack of cores.

This study aimed to (1) analyze the petrographic characteristics, electrofacies, and lithological distribution of the middle Miocene Sidri Member and (2) interpret and model the depositional environment of the middle Miocene Sidri sandstones based on the integration of GR patterns and lithological facies description. This work can be useful for the assessment of reservoir geometry, distribution, and quality in hydrocarbon reservoirs that lack conventional core samples. The work described here can also provide insights for reducing uncertainty during hydrocarbon field development in similar cases elsewhere.

\section{GEOLOGICAL BACKGROUND AND TECTONIC SETTING}

The divergence between the two continental plate tectonics of the African and Arabian plates resulted in forming the Red Sea rift system, which extends over $2500 \mathrm{~km}$ (Lyberis 1988; Bosworth et al. 1998). The northern part of the previously Cenozoic rift system is characterized by two different segments, which formed two gulfs, namely the Gulf of Suez and the Gulf of Aqaba. The Gulf of Suez is a NW-SE trending extensional rift basin (Fig. 1); it lies at the northern extension of the Red Sea rift system (Robson 1971; Lyberis 1988; Dolson 2020). The Gulf of Suez basin is about $300 \mathrm{~km}$ long, and it is structurally controlled by a dominant normal faulting system. This rift basin was formed during Oligocene-Miocene, and it is characterized by tilted fault blocks comprising half-graben and sub-basin architecture (Patton et al. 1994; Bosworth et al. 1998; Alsharhan 2003; Radwan et al. 2020a, b, c, d; Moustafa and Khalil 2020). Several hydrocarbon fields were discovered in this rift basin, and it can be classified as one of the most important hydrocarbon provinces in the world (Kassem et al. 2020; Radwan et al. 2020d). Based on dominant structural and bedding dips, the Gulf of Suez has been subdivided into northern, central, and southern provinces (Fig. 1) (Patton et al. 1994). 


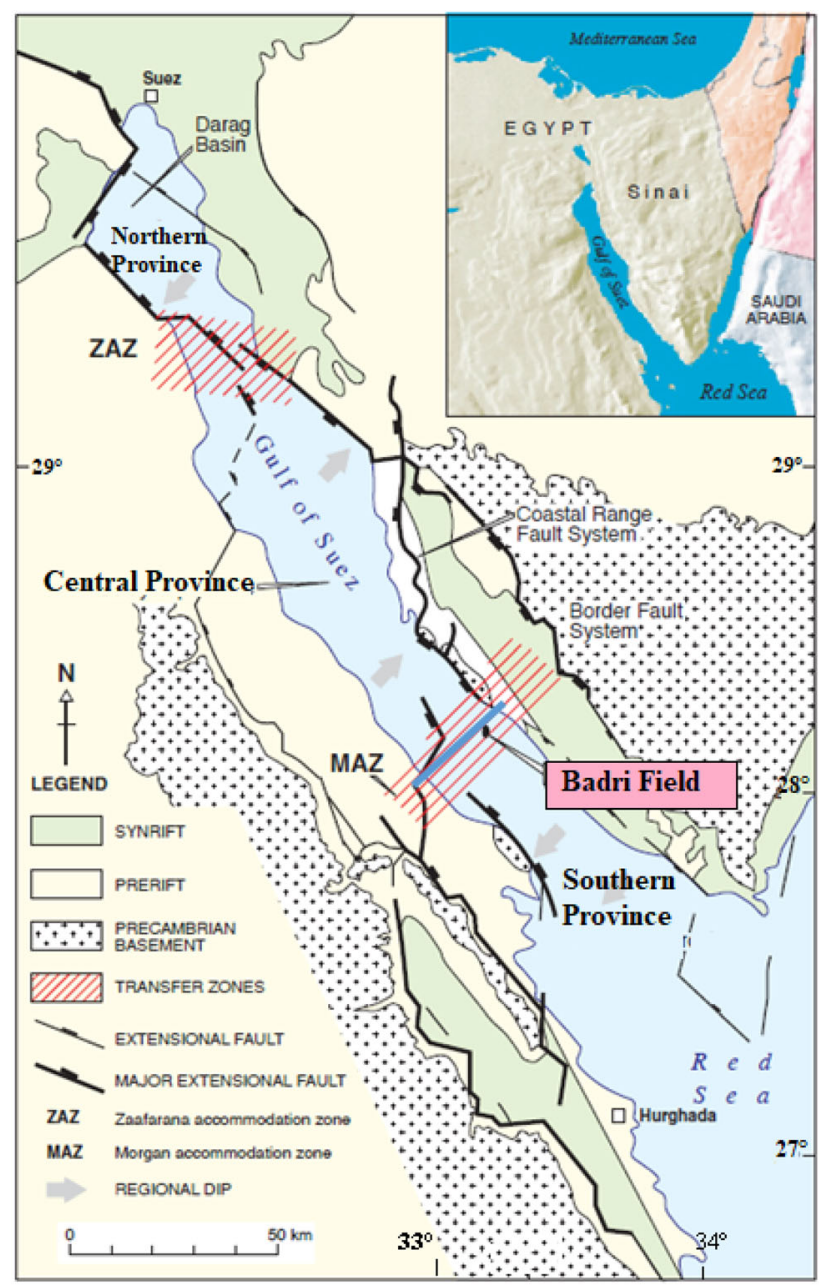

Figure 1. Location and tectonic map of the study area. Modified after Radwan et al. (2019b, 2020a). Extensional faults symbols, accomodation zones and regional dip from Khalil and McClay (2001). Blue line refers to the cross section in Figure 2.

The Badri oil and gas field is located in the offshore area of the basin, near the Sinai Peninsula shoreline, and it lies between latitudes $28^{\circ} 24^{\prime}$ and $28^{\circ} 26^{\prime} \mathrm{N}$ and longitudes $33^{\circ} 22^{\prime}$ and $33^{\circ} 47^{\prime} \mathrm{E}$ (Fig. 1) (Hughes and Beydoun 1992; Radwan 2018, $2020 \mathrm{a}, \mathrm{b}, \mathrm{c})$. The Badri field lies in the central province of the Gulf of Suez basin, where NE stratal-dip directions and southwestward fault-dip directions are dominant (Fig. 1). The giant El Morgan field is located to the west adjacent to the Badri field, while the East Badri field lies to the east (Fig. 2). These fields are located in a tilted fault-block setting, which formed during middle to late Miocene rifting (Radwan et al. 2019b, 2020a, c). With a throw of $460 \mathrm{~m}$ at the top of middle Miocene strata, an Edipping extensional fault bounds the field to the east and separates the Badri field from the adjacent East Badri field (Fig. 2) (Radwan 2014, 2018). Another E-dipping extensional with a throw of 75-245 m bounds the field to the west and separates it from the El Morgan field. At the middle Miocene reservoir levels, the field displays NW-SE anticlinal closure, while small faults with approximately $40 \mathrm{~m}$ throw compartmentalize the Badri field (Fig. 2) (EGPC 1996; Abudeif et al. 2016a, b, 2018). Middle Miocene sandstones are the main producers in the field, where the oil and gas column was discovered in 1982 in the Belayim and Kareem Formations (EGPC 1996). The middle Miocene Sidri and Baba Sandstones are the tertiary reservoirs in the Badri field (Abudeif et al. 2018; Radwan et al. 2020c). 


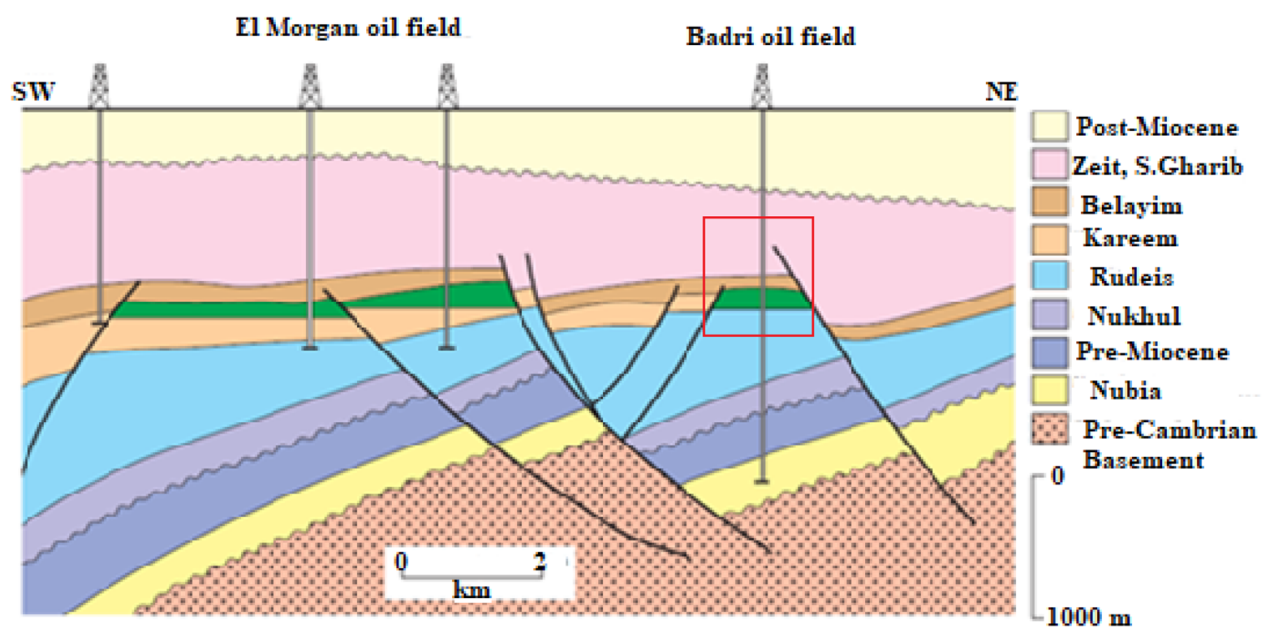

Figure 2. Southwest-northeast structural cross section through the El Morgan and Badri fields. Modified after EGPC (1996), Salah and Alsharhan (1997), Radwan et al. (2019a).

\section{STRATIGRAPHIC FRAMEWORK OF THE BADRI FIELD}

The stratigraphy of the Badri field consists of sediments with ages ranging from Carboniferous to Recent (Fig. 3) (Radwan 2014). Based on discoverable hydrocarbon in the middle Miocene formations, most wells reached below the oil-water contact of the Kareem Formation but do not penetrate the deeper strata of the wet Nubian sandstones (Carboniferous to Early Cretaceous). During the beginning of Langhian time (Kareem Formation), open marine conditions were recorded along the Gulf of Suez (EGPC 1996; Radwan and Sen 2020). Deep marine depositional conditions took place and resulted in the deposition of a thin anhydrite layer at the base of the Kareem Formation (Salah and Alsharhan 1997; Bosworth et al. 1998). The thin anhydrite layer is named Markha Member, and the most likely depositional conditions are related to hypersaline marine brines (EGPC 1996). As per continuous sea-level rise, an open marine condition prevailed resulting in progradation of fan-delta sandstone facies, and the continuous deposition was controlled by sea-level changes. Variable clastics filled up the tilted halfgraben blocks of the Badri field during the Kareem deposition time, and the deposition of an average $300 \mathrm{~m}$ thickness of the Kareem Formation continued until the mid-Serravallian (EGPC 1996). Later, the Belayim Formation rested unconformably on the previously deposited Kareem Formation. This formation shows fluctuating depositional environments, and it was deposited at the mid-upper Serravallian. Four sedimentation cycles were recorded during the Belayim sedimentation, resulting in the subdivision of the formation into four members. Two cycles consist of evaporites sequences (Baba and Feiran Members), and the other two cycles consist of intercalated clastics (Sidri and Hammam Faraun Members) (Hughes and Beydoun 1992; Nabawy and El Sharawy 2015; Nabawy and Barakat 2017; Radwan et al. 2019a, b, c, d, 2020a, c). The deposition of the Belayim Formation (14-10.4 Ma) started with sedimentation of an average $20 \mathrm{~m}$ of evaporites sequences with thin intercalated shale and sandstone streaks (Radwan et al. 2020c). The deposition of evaporites resulted due to the restriction between the Mediterranean Sea and the Gulf of Suez at that time, which resulted in a fall in sea level (Patton et al. 1994). The sea level rose again, returning to the open marine conditions, and resulted in the deposition of an average $20 \mathrm{~m}$ of clastics during the deposition of the Sidri Member. Returning to restricted conditions, thick evaporite sequences were deposited during the deposition of the Feiran Member (Abudeif et al. 2016a, b). The sea level rose again during the deposition of the Hammam Faraun Member, and open marine conditions prevailed resulting in the progradation of fan-delta sandstone facies at Serravallian time (Attia et al. 2015). In contrast, the late Miocene sediments displayed a more restricted condition. Following the deposition of the previously mentioned formations, a thick evaporite sequence reaching up to $900 \mathrm{~m}$ with dominant halite was deposited during the deposition of the 


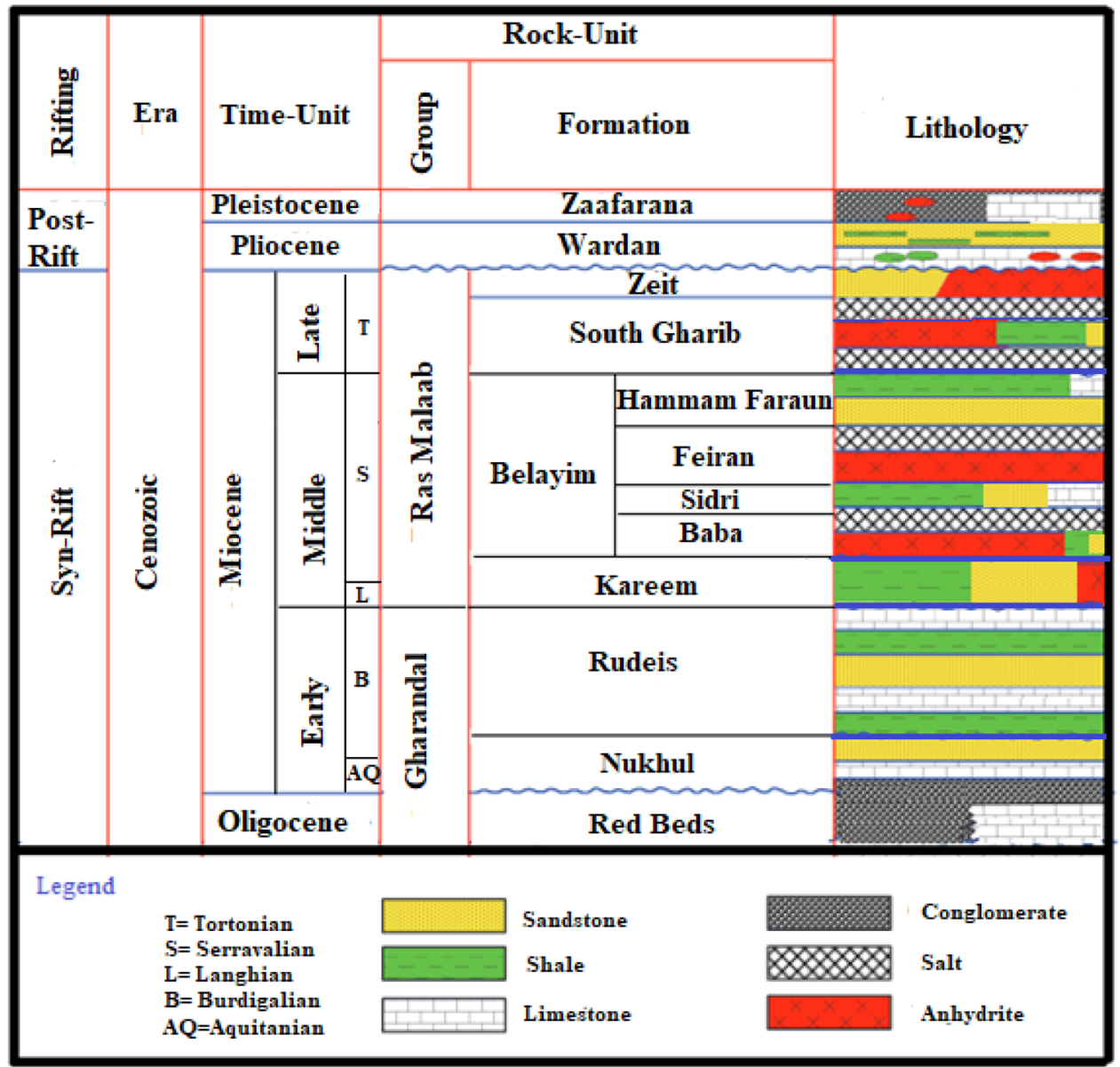

Figure 3. Miocene lithostratigraphic column of the Badri field, Gulf of Suez. Adapted from Radwan (2014, 2018), Radwan and Sen (2020).

South Gharib Formation. Continuing with restricted conditions, thick intercalated evaporites and clastics streaks were deposited during the sedimentation of the Zeit Formation. The post-Miocene sediments were named Post-Zeit Formation; it consists of sand, clay, gypsum, and limestone, which rests unconformably on the late Miocene Zeit Formation. The depositional environment of the Zeit Formation is varied between continental and marine conditions.

\section{MATERIALS AND METHODS}

\section{Materials}

This study is based on wireline logs, and it incorporates ditch cutting descriptions and analysis, due to the absence of core data in the studied interval. Datasets of well logs from 40 wells were employed to determine the facies distribution of the middle Miocene Sidri Member in the Badri field. Only four wells (Fig. 4) were used for the data presented in this paper due to restricted data sharing policy of the providing organization. The four wells are denoted as wells 1, 2, 3, and 4 (Fig. 4), and the available data are listed in Table 1 . The selected wells have a full suite of logs; they are located between the primary producing reservoirs in the Badri field, and the borehole conditions are excellent. Two wells (1 and 3) are located in the northern part of the Badri field, while the other two wells are located in the southern part (Fig. 4). The thickness of the Sidri Member in the Badri field is varied and less uniform; it reaches a maximum thickness of $41 \mathrm{~m}$ in well 3 and $37 \mathrm{~m}$ well 1 , while it reaches a maximum thickness of 17 and $18 \mathrm{~m}$ in wells 2 and 4, respectively. The sandstone intervals of the middle Miocene Sidri Member are scattered in some parts of the 


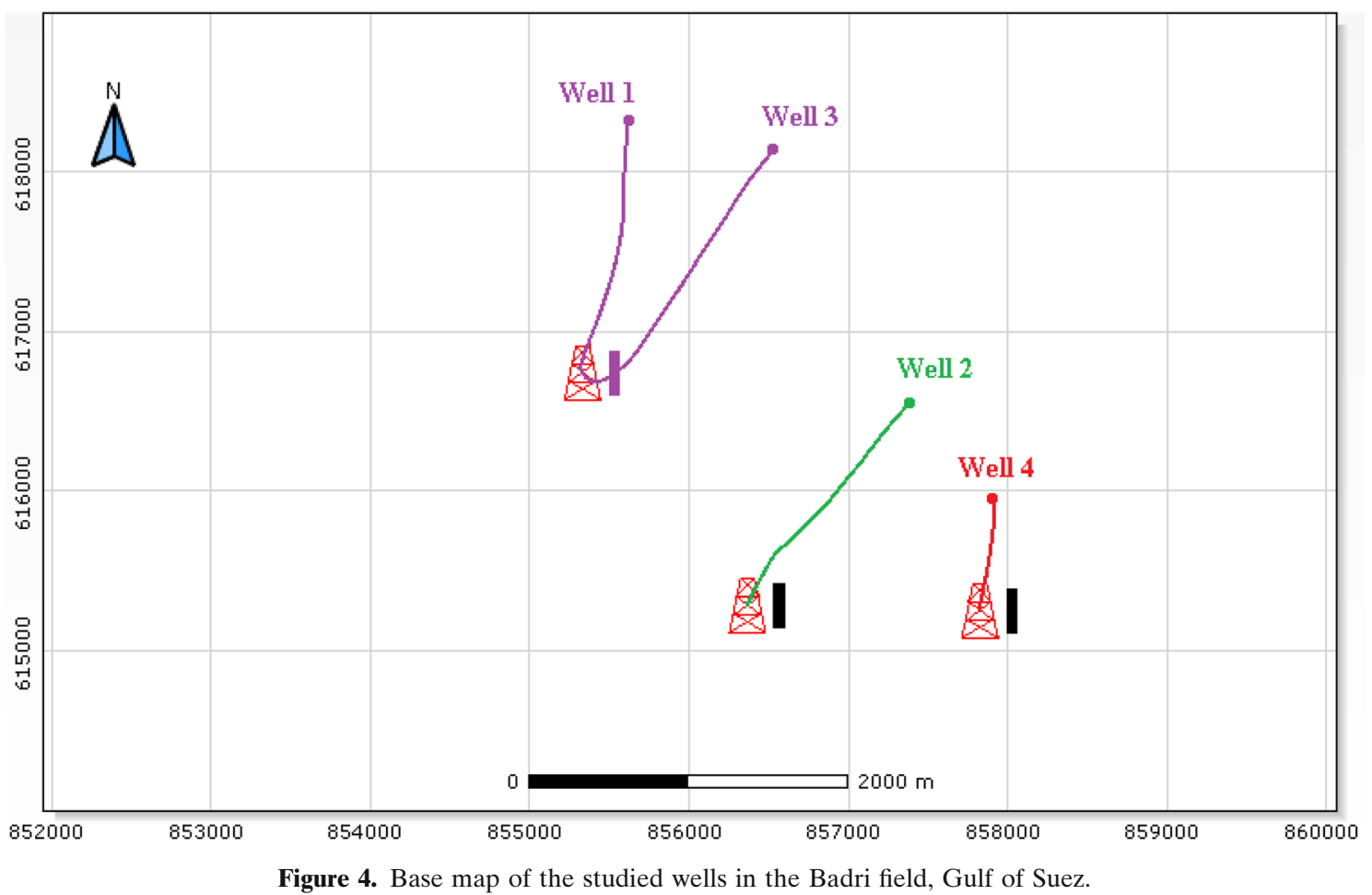

Table 1. Available well logging and different logs data in the studied wells

\begin{tabular}{|c|c|c|c|c|c|c|c|c|c|c|c|}
\hline \multirow[t]{2}{*}{ Well } & \multicolumn{2}{|c|}{ Sonic } & \multicolumn{2}{|c|}{ Gamma ray } & \multicolumn{2}{|c|}{ Deep resistivity } & \multicolumn{2}{|c|}{ Neutron porosity (NPHI) } & \multicolumn{2}{|c|}{ Density (RHOB) } & \multirow{2}{*}{$\begin{array}{l}\text { Composite, mud log } \\
\text { and geological reports }\end{array}$} \\
\hline & From & To & From & To & From & To & From & To & From & To & \\
\hline 1 & 177 & 2878 & 190 & 2877 & 1487 & 2877 & 1487 & 2877 & 220 & 2877 & $\mathrm{x}$ \\
\hline 2 & 1700 & 2305 & 1700 & 2305 & 1700 & 2305 & 1702 & 2305 & 1702 & 2305 & $\mathrm{x}$ \\
\hline 3 & 2140 & 2870 & 2130 & 2870 & 2140 & 2868 & 2142 & 2868 & 2142 & 2868 & $\mathrm{x}$ \\
\hline 4 & 1808 & 2210 & 1786 & 2210 & 1810 & 2211 & 1815 & 2213 & 1820 & 2213 & $\mathrm{x}$ \\
\hline
\end{tabular}

field and are represented by wells 1 and 3, while thick sandstone units developed in the northern part of the Badri field and represented by well 2 . The top and bottom of the middle Miocene Sidri Member, sandstone intervals, average porosity, and shale volume are described in Table 2. However, the middle Miocene Sidri sandstone is very heterogeneous, which makes it difficult to classify it into reservoir units using conventional petrophysics analysis (Abudeif et al. 2016b). The principal data used logs in this study were (1) GR, which was used for facies correlation and depositional environment interpretations, and (2) density logs (RHOB), neutron logs (NPHI), and resistivity, which were used for lithology confirmation and facies correlations. Due to the absence of core data from the middle Miocene Sidri Member, data from ditch cuttings were utilized for petrographic description. Thirty samples were collected from the studied wells. These samples were coded from S1 to S30, representing the upper (S1-S10), middle (S11-S20), and lower (S21S30) parts of the Sidri sandstone, and their analyses are given in Table 3. Thirty thin sections were prepared for describing the sedimentological features of the studied zone. Composite logs and geological reports were available and taken into consideration in the evaluation and interpretation processes. 
Table 2. Summary of stratigraphic intervals of the studied wells and average petrophysical characteristics of the Sidri Member in the Badri field

\begin{tabular}{|c|c|c|c|c|c|}
\hline Variable & Unit & Well 1 & Well 2 & Well 3 & Well 4 \\
\hline Top of the Sidri Member & $\mathrm{m}$ & 2490 & 1932 & 2387 & 2130 \\
\hline Base of the Sidri Member & $\mathrm{m}$ & 2527 & 1949 & 2428 & 2148 \\
\hline Thickness of the Sidri Member & $\mathrm{m}$ & 37 & 17 & 41 & 18 \\
\hline Top of the Sidri sandstone reservoir & $\mathrm{m}$ & 2495 & 1935 & 2387 & - \\
\hline Bottom of the Sidri sandstone reservoir & $\mathrm{m}$ & 2522 & 1947 & 2428 & - \\
\hline Gross thickness & $\mathrm{m}$ & 27 & 12 & 41 & - \\
\hline Net pay thickness (h) & $\mathrm{m}$ & 27 & 7 & 41 & - \\
\hline Average shale volume (Vsh) & $\%$ & 9 & 19 & 10 & 100 \\
\hline Average porosity $(\varnothing)$ & $\%$ & 19 & 18 & 17 & - \\
\hline
\end{tabular}

Well 4 has pure shale interval. The depth is in measured depth

\section{Methods}

Wireline logging, composite logs, and geological reports were incorporated to evaluate the Sidri clastics and delineate its facies distribution, supported by petrographic analysis. The adopted research workflow in this work incorporated the determination of sandstone thickness using well logging data, as well as petrographic description and analysis. In the second stage, the facies distribution map of the middle Miocene Sidri Member was generated according to the facies correlation through the field. Later, the GR log trends were utilized to interpret the depositional settings of the studied zone, and the electrofacies were defined and linked with the previous petrographic analysis.

\section{Lithology and Sedimentological Features}

Lithology determination is an essential step in reservoir evaluation; it can be determined directly through thin sections analysis (Dott 1964). Electric logs cross-plots and well logging relations (e.g., density-neutron) can be used in lithology determination as indirect methods (Abudeif et al. 2016a, 2018). Attia et al. (2015) stated that the middle Miocene sandstones in the Badri field are characterized by high GR readings due to the presence of K-feldspars, which makes interpretation of the studied facies challenging. The existence of feldspars grains in the middle Miocene Belayim Formation including the Sidri Member reflects the high GR response of the Sidri sandstones. Thus, the densityneutron log signature was utilized for lithology identification in the studied zone and incorporated with the cutting and thin section description. Al- though GR logs do not help in lithology identification, they are useful for correlation of the Sidri Member within the field, which can be distinguished easily from the lower and higher boundaries.

The thin section samples were prepared from the available ditch cuttings and examined under a Nikon polarized microscope, due to the absence of core samples in the studied intervals. The petrographic description of the middle Miocene sandstones encompasses the analysis of matrix, texture, grains, roundness, and sorting. Sandstones were classified based on Dott (1964). Sedimentological features have been inferred from the examination of rock constituents. The grain size of the Sidri sandstones was analyzed by sieve analysis to detect the sign of hydraulic energy. In addition, grain roundness and sorting were analyzed from 30 samples of the Sidri sandstone reservoir to interpret the paleoenvironment and the physical conditions. The porosity of the Sidri sandstones was estimated using the point count method and tabled per each sample (Table 3). The sedimentary structure of the studied reservoir cannot be detected due to core absence.

\section{Lithofacies Distribution and Depositional Environ- ment}

Generally, the depositional environment of Sidri Member in the Gulf of Suez allows for the deposition of different clastic lithologies included shales, sandstone, and lesser limestone beds. The deposition time of Sidri Member is characterized by rises in sea level and marine conditions. These conditions allow for the deposition of varied lithology, which is controlled by sea-level changes. The examined lithofacies from the well logs and ditch 


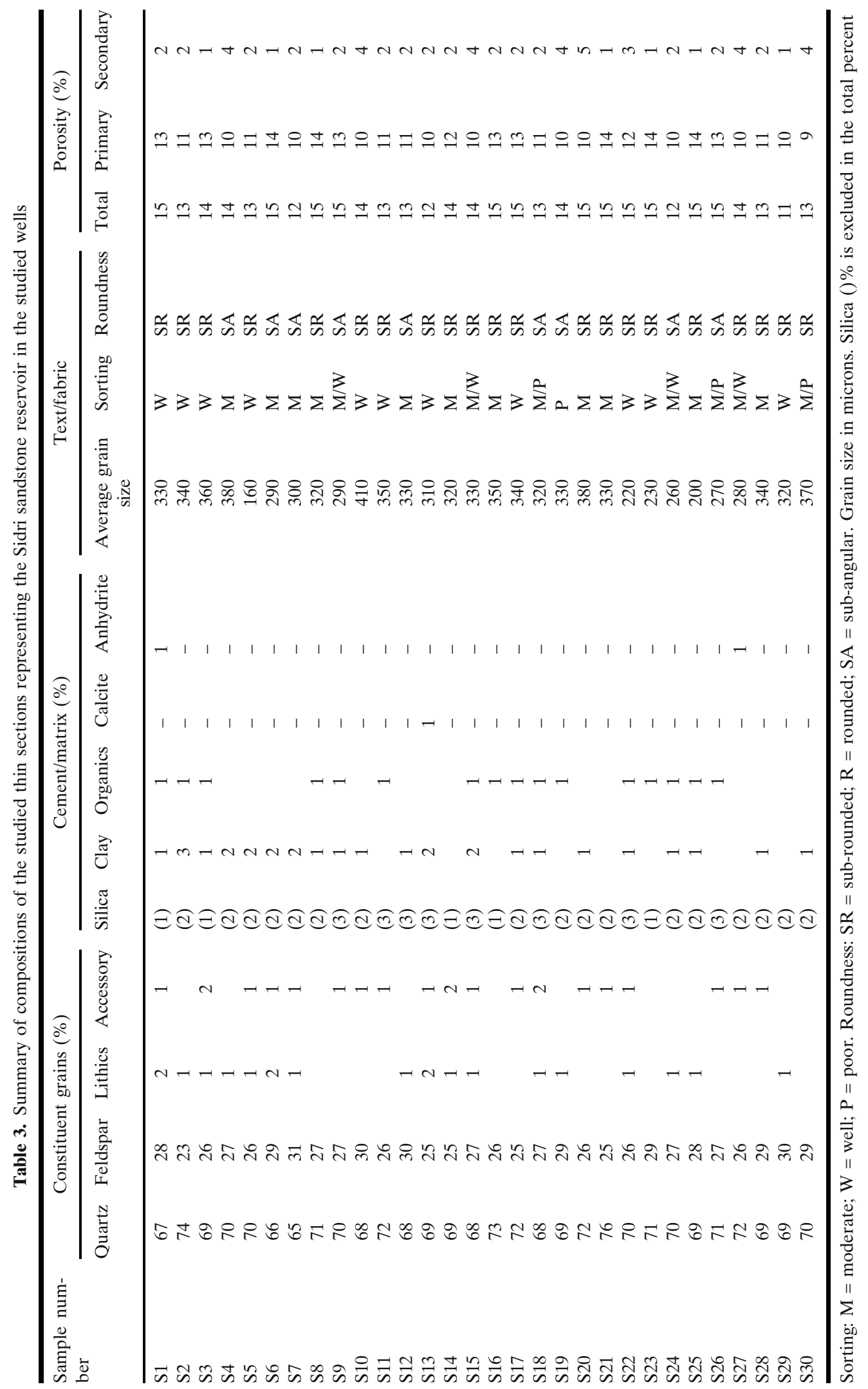


cuttings were used to construct a lithofacies distribution map of the middle Miocene Sidri Member. To understand the lithological heterogeneity and their lateral extent in the middle Miocene Sidri Member, a well logging correlation from one well to another was employed based on the similarity of logging curves and choice of correlatable markers. Sandstones and shales thicknesses in the Sidri member and their vertical and lateral distributions were investigated per well and correlated through the field. Later, the facies was plotted on a geological map according to the positions of the wells in the Badri field to show the facies distribution of the sandstones of interest within the field.

\section{Electrofacies Interpretation from GR Log}

Well logs are commonly used for subdividing subsurface sequences into different electrofacies, which have similar patterns and differ from other units. Systematic application of logs was developed in the last decades and used for sedimentological studies of hydrocarbon reservoirs (Pirson 1963; Serra 1989; Posamentier and Allen 1999; Baouche et al. 2020). Selley (1978) argued that well-log curves (e.g., GR and SP) reflect the grain size distribution in sedimentary successions and, thus, the depositional environment of rock successions. Later, many researchers have introduced and applied some classifications for different log-curve shapes to interpret depositional facies in subsurface sections based on log-curve patterns (Garcia 1981; Serra 1989; Rider 1990; Wagoner et al. 1990; Boggs 1995; Emery and Myers 1996; Olayiwola and Bamford 2019). Among the well-log curves, GR patterns are the widely used $\log$ curves for analysis of subsurface depositional environment (Rider 1990; Cant 1992; Chow et al. 2005). Cant (1992) divided GR curve shapes into five patterns that reflect different depositional environments, and used SP logs as well. The GR patterns include cylindrical/boxcar, funnel shape, bell shape, bow, and irregular shapes (Cant 1992) (Fig. 5).

\begin{tabular}{|c|c|c|c|c|c|}
\hline GR Log Pattern & Cylindrical/ Boxcar & Funnel & Bell & Symmetrical & Serated//rregular \\
\hline GR Trend & Low GR High GR & $\begin{array}{l}\text { Coarse } \\
\text { Up \& } \\
\text { Sharp top }\end{array}$ & $\begin{array}{l}\text { e Up } \\
\text { Sharp } \\
\text { se }\end{array}$ & s & . \\
\hline Sediment Supply & Agrrading & Prograding & Retrograding & $\begin{array}{l}\text { Prograding \& } \\
\text { Retrograding }\end{array}$ & Aggrading \\
\hline $\begin{array}{l}\text { Depositional } \\
\text { Environment } \\
\text { (Common) }\end{array}$ & $\begin{array}{l}\text { Fluvial channels } \\
\text { Carbonate shelf, } \\
\text { Reef, Submarine } \\
\text { canyon fill, } \\
\text { Prograding delta } \\
\text { distributaries, } \\
\text { Aeolian dunes, } \\
\text { evaporite fill of } \\
\text { basin }\end{array}$ & $\begin{array}{l}\text { Crevasse splay, } \\
\text { River, Mouth } \\
\text { bar, Delta } \\
\text { front, } \\
\text { shoreface, } \\
\text { Submarine fan } \\
\text { lope }\end{array}$ & $\begin{array}{l}\text { Fluvial Ppoint } \\
\text { bar, Tidal point } \\
\text { bar, deep tidal } \\
\text { channel fill, } \\
\text { Deltaic } \\
\text { channels, } \\
\text { proximal deep } \\
\text { sea settings, } \\
\text { Tidal flats }\end{array}$ & $\begin{array}{l}\text { Reworke offshore } \\
\text { bar, regressive to } \\
\text { transgressive shore } \\
\text { face delta, }\end{array}$ & $\begin{array}{l}\text { Fluvial flood } \\
\text { plain, Storm } \\
\text { dominated } \\
\text { shelf, mixed } \\
\text { Tidal flat, } \\
\text { Debris flow, } \\
\text { Canyon fill, } \\
\text { Deep marine- } \\
\text { slope }\end{array}$ \\
\hline
\end{tabular}

Figure 5. Common sedimentological facies associated with various gamma-ray log shapes. Modified after Cant (1992). 
Electromagnetic waves with frequencies between $10^{19}$ and $10^{21} \mathrm{~Hz}$ are called gamma rays (Serra 1989; Ellis and Singer 2007). The GR log reflects the total radiation of equivalent uranium (eU), equivalent thorium (eTh), and potassium (K) within a certain formation. These radioactive elements are contained sediments in the form of accessory minerals (Ellis and Singer 2007; DíazCuriel et al. 2019). The GR curve reflects the total radiation of the mentioned elements, which have different energy peaks that are equivalent to $1.46 \mathrm{MeV}, 1.76 \mathrm{MeV}$, and $2.62 \mathrm{MeV}$ for $\mathrm{K}, \mathrm{U}$, and Th, respectively (Blum et al. 1997; Ellis and Singer 2007; Skupio et al. 2019). Based on their different energy peaks of radiation, a spectral GR device can divide the total radiation curve into three curves representing each of the three radioactive elements. The relation between the total GR signals in API can be expressed as:

$$
\mathrm{GR} \quad \mathrm{API}=\alpha \mathrm{U}+\beta \mathrm{Th}+\gamma \mathrm{K}
$$

where $\mathrm{U}$ and $\mathrm{Th}$ are concentrations of these elements in ppm, $\mathrm{K}$ is potassium concentration in weight percent, and $\alpha, \beta$, and $\gamma$ are the mass concentration units of the radioactive isotopes and for standard ones, too. The values for $\alpha, \beta$, and $\gamma$ are 4, 8 , and 16, respectively (Ellis and Singer 2007; Skupio et al. 2019).

GR log patterns were used to interpret the depositional settings of the Sidri Member facies based on previous approaches (e.g., Selley 1978; Cant 1992; Chow et al. 2005; Ellis and Singer 2007; Nazeer et al. 2016; Ashraf et al. 2019; El-Tehiwy et al. 2019). The depositional environment of the studied reservoir was interpreted based on the GR $\log$ and the petrographic characteristics. In this work, the electrofacies of the middle Miocene Sidri Member were identified based upon the different

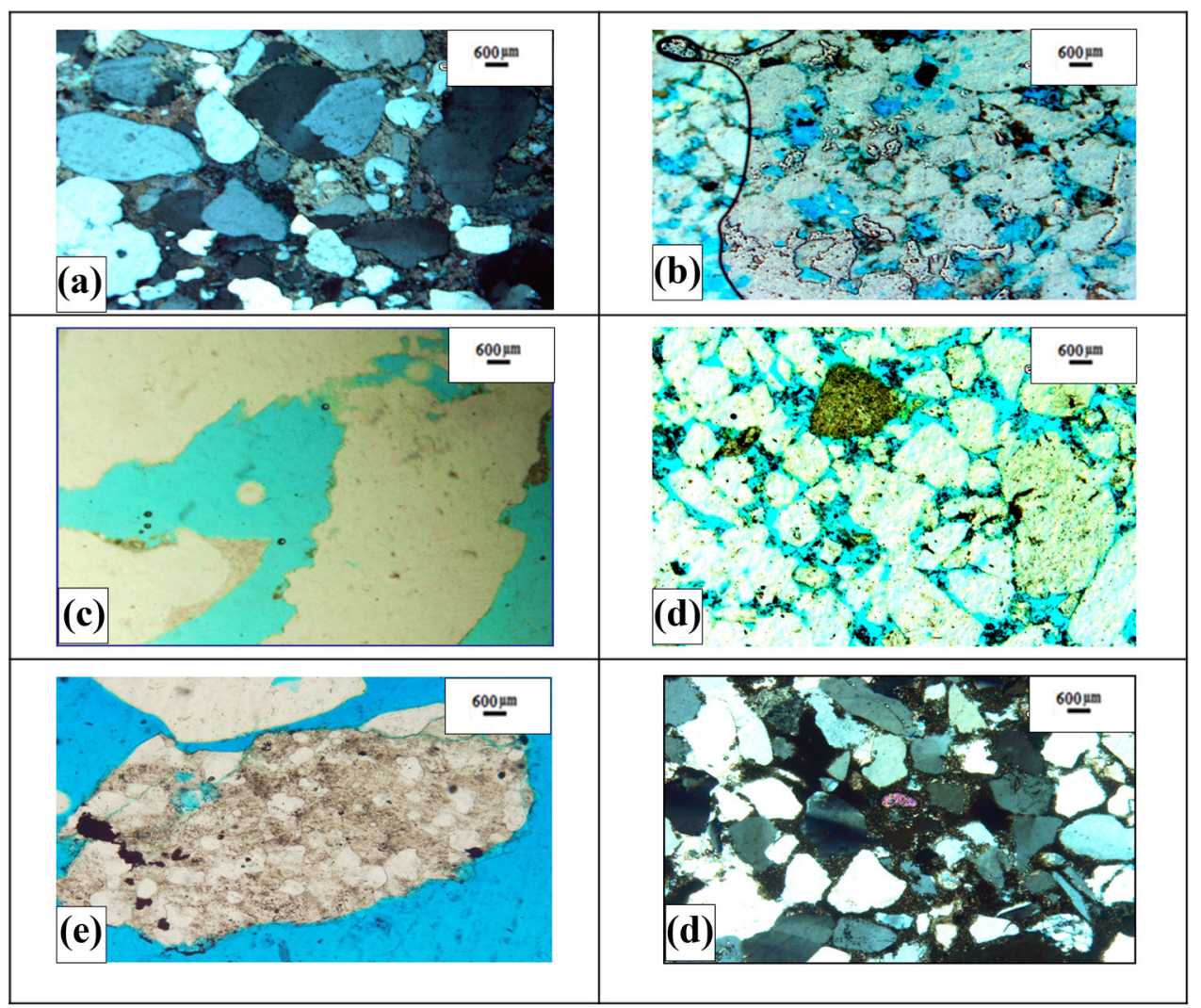

Figure 6. Micro-photographs from the studied wells. (a) Medium-size sand grains cemented by calcareous cement; magnification $125 \times$, sample depth $2400 \mathrm{~m}$. (b) Inter-granular porosity; magnification $125 \times$, sample depth $2515 \mathrm{~m}$. (c) Porosity; magnification 80x , sample depth $2410 \mathrm{~m}$. (d) Microcline within composite quartz grains; magnifications $80 \times$, crossed nicols, sample depth $1941 \mathrm{~m}$. (e) Organic materials between grains; magnifications $80 \times$, sample depth $2420 \mathrm{~m}$. (f) Composite quartz grains with accessory minerals; magnifications 80× , sample depth 2530 m (Radwan 2014; Attia et al. 2015; Abudeif et al. 2016b). 
patterns of GR log. Accurate electrofacies definition is of great importance for facies interpretation; however, it should be combined with lithofacies characteristics to interpret the depositional environment. GR patterns of the middle Miocene Sidri Member were equally placed at the same level to facilitate correlation. Then, similar lithologies were matched and similar GR signatures were spotted for facies interpretation and for distinguishing the different depositional settings within the studied zone. The used GR baseline in the middle Miocene Sidri sandstone is 75 API. In addition, the grain size characteristics were taken into consideration while interpreting the depositional settings of the defined electrofacies.

\section{RESULTS AND DISCUSSION}

\section{Petrographic Analysis and Sedimentological Features}

Based on thin section sample analysis, ditch cuttings, and well logging analysis, the stratigraphic section of Sidri Member consists of fine- to mediumgrained clastic sediments. Shales and sandstones are the dominant lithologies with minor highly argillaceous limestone streaks. Shale is characterized by dark gray color, moderately hard, sub-blocky, and non-calcareous to slightly calcareous. Limestone is characterized by gray colors, moderately hard, highly argillaceous. The petrographic characterization of the Sidri sandstones is discussed below.

\section{Grain Framework}

The most abundant mineral constituents of the middle Miocene Sidri sandstone are quartz grains, averaging $70 \%$ of the individual samples, where porosity was excluded in the total rock constituent calculations (Fig. 6). The minimum value of quartz was $65 \%$, which is recorded at the upper part of the Sidri sandstones, while the maximum value reached $76 \%$ at the basal part (Table 3). Monocrystalline and polycrystalline quartz grains were visible in thin sections of many samples. Feldspars were recorded in all samples; they were the second most dominant constituent grains after quartz grains. Plagioclase is also dominant; however, microcline is also present only in some samples. Feldspars average $27 \%$ of the total mineral constituent of the samples, the mini- mum value was $23 \%$ and it was recorded in the basal part of Sidri sandstones, while the maximum value reached $31 \%$ at the upper part of Sidri sandstones. Lithic fragments are less abundant in the middle Miocene Sidri sandstones, where it averaged between 1 and $2 \%$; metamorphic fragments were dominant. Accessory minerals averaged between 1 and $2 \%$; pyrite was more abundant than mica.

\section{Texture and Fabric}

Quartz grains showed sub-angular to sub-rounded characteristics; however, sub-rounded characteristics were more dominant in the succession. The grain sizes in the middle Miocene Sidri sandstone reservoirs in the Badri area ranged from fine to medium. Sandstone grain sizes averaged $312 \mathrm{mi}-$ crons of the total samples, the minimum value was 160 microns and it was recorded in the upper part of Sidri sandstones, while the maximum value reached 410 microns at the basal part intervals of Sidri sandstones (Table 3). The grains show moderate to well sorting in most samples; however, poorly sorted textures were recorded in some samples.

\section{Cement and Matrix}

All analyzed samples of the Sidri sandstones were cemented by silica, while anhydrite and carbonate cementation was less abundant. Organic materials were visible as dark spots in some samples of the Sidri sandstones (Fig. 6). Silt-sized grains and clays were the abundant pore-filling matrix in the middle Miocene Sidri sandstones.

\section{Porosity}

Primary and secondary porosity was developed in the Sidri sandstones. Primary porosity was dominant than the secondary one; the latter was formed by diagenetic process. Sandstone total porosity from the point count method averaged $13.8 \%$; the minimum value was $11 \%$, and it was recorded in the lower part of Sidri sandstones, while the maximum value reached $15 \%$ along with the Sidri sandstones intervals (Table 3). Inter-granular porosity type was dominant along the section; however, plagioclase grain dissolution resulted in various percentages of intra-granular porosity as secondary porosity type 


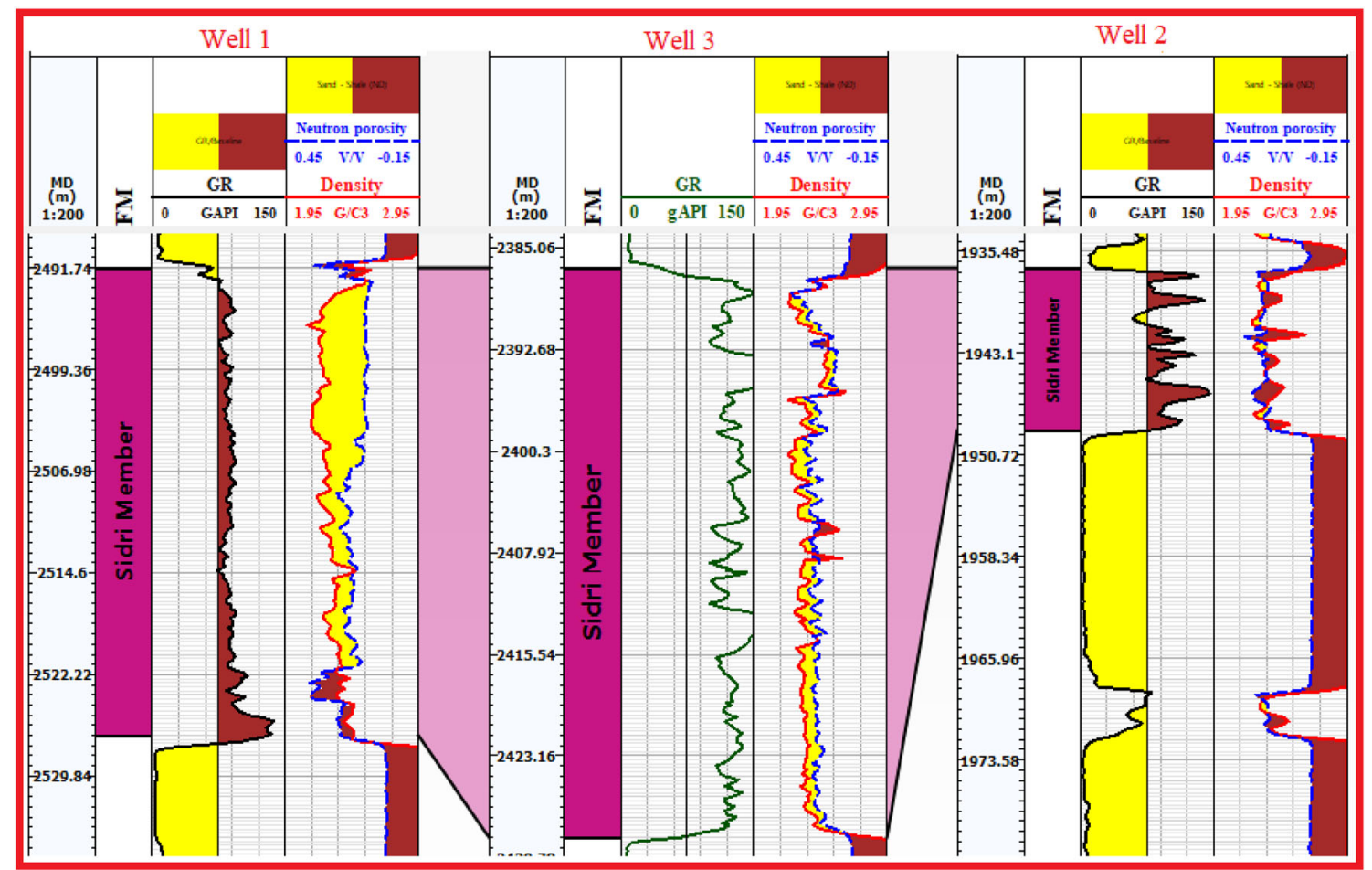

Figure 7. Stratigraphic correlation of Sidri sandstone facies through Badri field, Gulf of Suez (wells 1, 2, and 3).

(Fig. 6). Secondary porosity averaged $2 \%$ of the total porosity, the minimum value was $1 \%$ and it was recorded in the upper and lower parts of the Sidri sandstones, while the maximum value reached $5 \%$ at the upper part of the Sidri sandstones.

\section{Diagenetic Features}

The effect of diagenetic process on the studied sandstones was observed as leaching of feldspar grains forming secondary porosity (Fig. 6). In some samples, feldspars showed some alteration to clays along cleavage planes and grain surfaces; in many samples, diagenetic dissolution was recorded as well. In contrast, compaction process was observed as concave-convex contacts, as well as abundance of clay and dolomitic cement, which refers to cementation that negatively affects the porosity and permeability in the studied zone (Fig. 6). Organic materials in the thin sections may reflect oil-bearing sandstone (Fig. 6).

Polycrystalline and monocrystalline quartz and angular to sub-rounded feldspars indicate short transport from a nearby source (Tucker 1981). The source of the Sidri sandstone could be from the nearby hills of igneous and metamorphic rocks according to the polycrystalline quartz grains. The analysis of lithological compositions of the middle Miocene Sidri Sandstones indicated dominant feldspathic sandstone, with average composition percentages in samples Q70, F27, and L3, which are classified as arkose based on the high percentages of quartz and feldspars. According to these lithological characteristics, the Sidri sandstone can act as a good reservoir.

\section{Electrofacies Distribution and Correlation of the Middle Miocene Sidri Member}

According to the screening work of wireline logging, composite logs, and sample descriptions of the 42 drilled wells in the Badri field, three facies were detected in the studied Sidri Member. The well logging datasets of the wells were correlated through the field (Fig. 7). GR patterns and density-neutron logs were found to correlate with three different electrofacies that match with distinguished lithology. The thickness of the Sidri member reached a maxi- 
mum of $40 \mathrm{~m}$ in the field. The lithological facies of Sidri member are distributed into three different facies within the field, namely (1) blocky sandstone, (2) intercalated sandstone, and shales streaks with minor highly argillaceous limestone, and (3) shaly facies. Later, the detected facies was plotted on the structure contour map of the Sidri member (Fig. 8). The characteristics of the recognized electrofacies are discussed below.

\section{Electrofacies-A (Blocky Sandstones)}

This is the least dominant facies in the Sidri member. It is concentrated only in the northern part of the field. The thickness of this facies reached up to $15 \mathrm{~m}$. These successions were characterized by a cylindrical-shaped (right boxcar) GR trend and relatively constant GR response; it can be distinguished easily by its sharp contact with the lower and upper anhydrite lithology (Fig. 9). This right boxcar GR pattern refers to constant lithology (e.g., Selley 1978; Ashraf et al. 2019; El-Tehiwy et al. 2019) (Fig. 1). The ideal lithology of this electrofacies is fine- to medium-grained sandstone, which matches the well data findings. The average GR varies from 75 to 110 API (Table 4); the high GR readings are related to the K-feldspars present, and the used baseline was dependent on the GR values per well. These successions comprise $10 \%$ of the total facies.

\section{Electrofacies-B (Intercalated Sandstones and Shales)}

This is the most dominant facies in the study area. It is distributed mainly in the southern and middle parts, as well as in the northern part of the field (Figs. 8 and 9). These successions comprise $70 \%$ of the total facies. The thickness of sandstone layers within this facies ranged between 1 and $3 \mathrm{~m}$, while the total thickness reached $40 \mathrm{~m}$. This electrofacies was characterized by an irregular log trend with a serrated shape, which could reflect the aggradation of grain size (Emery and Myers 1996). The lithological description of this electrofacies as intercalated fine- to medium-grained sediments matched the previous GR patterns findings (Fig. 9). The average GR was +90 API (Table 4).

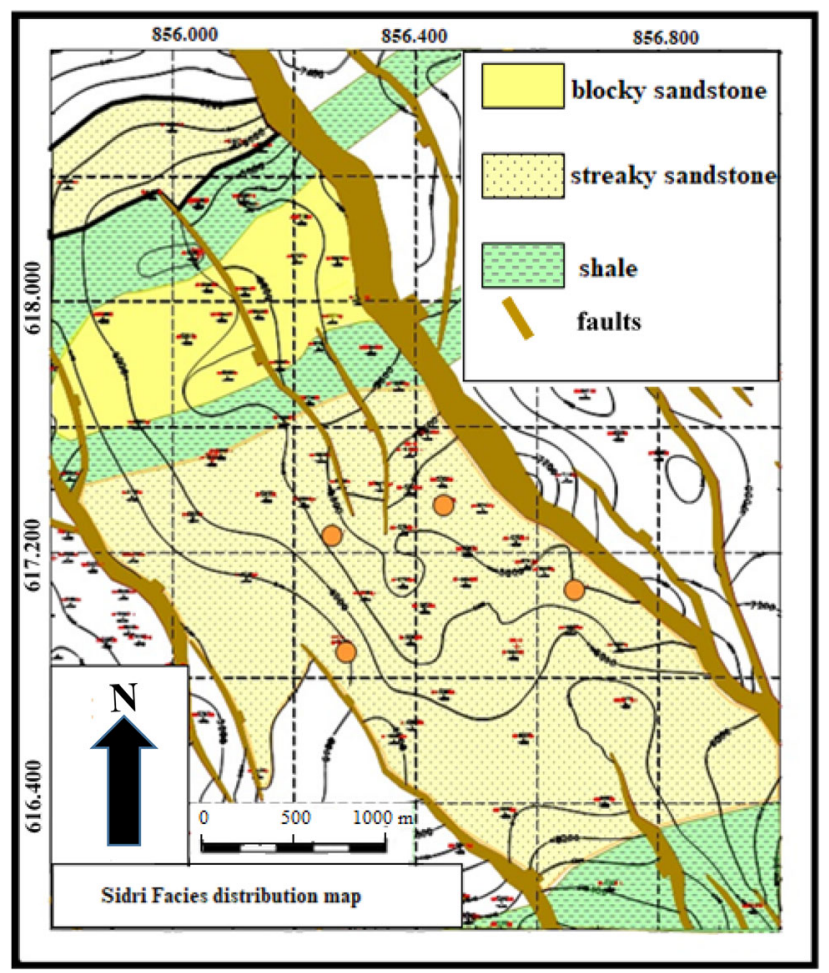

Figure 8. Facies distribution map of the Sidri Member in the Badri field. 


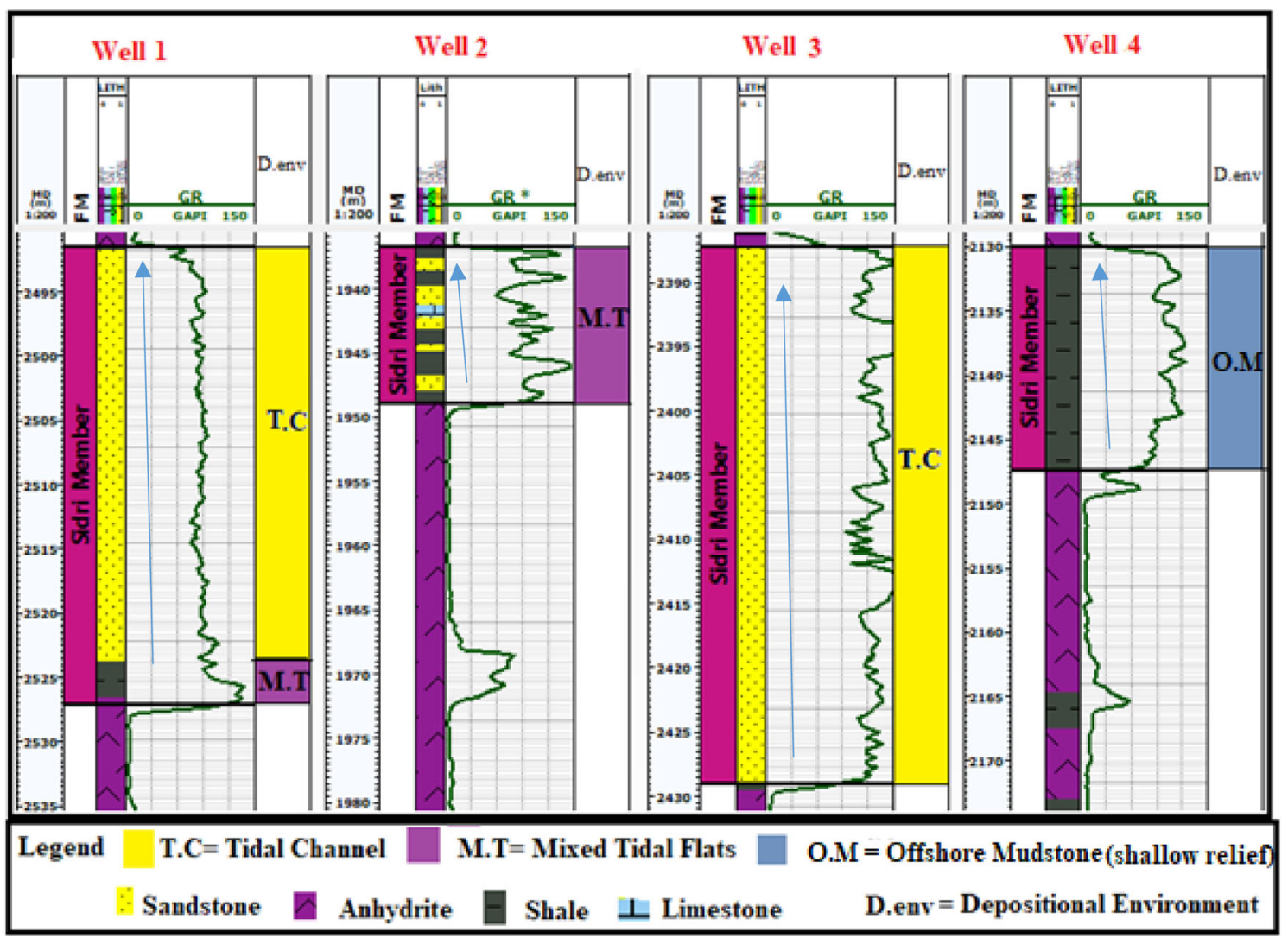

Figure 9. Interpreted depositional environments in the Sidri Member using the gamma-ray log shapes.

\section{Electrofacies-C (Shales)}

Electrofacies 3 is the second most dominant facies in the Sidri member. It is concentrated in two areas within the field: the first area in the southern part of the field and the second area in the northern part where it is bounded by the blocky sandstone facies. The thickness of this facies ranged from 20 to $40 \mathrm{~m}$. These successions were characterized by irregular GR trends and have no character (Fig. 9). These successions comprise $20 \%$ of the total facies. The lithological description of this electrofacies as fine-grained mudstone matched the well data findings. The average GR was +95 API (Table 3).

\section{Deduction of Depositional Environment of the Sidri Member and Sandstone Reservoirs}

The GR log is one of the basic tools that can indicate deposition break in a sedimentary succession, where log values reflect changes in lithology, grain size, clays, accessory minerals, and depositional system. However, interpretation of depositional settings requires support of regional information about the sedimentological framework of an area. In the studied Serravallian reservoir, two sharp deposition breaks were detected by the sharp contrast of GR trends, which confirm different depositional settings boundaries between the studied reservoir and both upper and lower sections. The first break was the sharp change in GR values, from clean GR of the lower Baba member anhydrite to high GR values of the studied sandstones reservoir, which represents a sharp deposition break at the lower part of the studied section (Fig. 9). With this deposition break, the anhydrite facies or lagoon deposits are overlain by marine environment sandstone/shales. In addition, the lack of a transitional zone is another confirmation of different depositional regimes between facies. The second break is the sharp change in GR values, from high GR values of the studied sandstones reservoir to clean GR of the upper Feiran member anhydrite, which repre- 
Table 4. Summary of gamma-ray trends, electrofacies, depositional environments, and lithofacies in the Badri field

\begin{tabular}{|c|c|c|c|c|c|}
\hline Electrofacies & $\begin{array}{l}\text { Depositional } \\
\text { environment }\end{array}$ & Gr trends & $\begin{array}{l}\text { Dominant lithol- } \\
\text { ogy }\end{array}$ & $\begin{array}{c}\text { Average } \\
\text { GR } \\
\text { (API) }\end{array}$ & Lithofacies characteristics \\
\hline EF-1 & Tidal channel & $\begin{array}{l}\text { Cylindrical- } \\
\text { shaped (ser- } \\
\text { rated) }\end{array}$ & Sandstone & $75-110$ & $\begin{array}{l}\text { Thick beds of medium to fine sandstone with good } \\
\text { sorting and sub-angular to sub-rounded shapes }\end{array}$ \\
\hline EF-2 & Mixed tidal flats & Irregular shape & $\begin{array}{l}\text { Intercalated } \\
\text { sandstone and } \\
\text { shales }\end{array}$ & $90+$ & $\begin{array}{l}\text { Intercalations of thinly laminated beds of sandstone } \\
\text { and mud, with very minor limestone streaks }\end{array}$ \\
\hline EF-3 & $\begin{array}{l}\text { Offshore mud- } \\
\text { stone (shallow } \\
\text { relief) }\end{array}$ & Irregular shape & Shales & $100+$ & Fine-grained shales \\
\hline
\end{tabular}

sents a sharp deposition break at the upper part of the studied section (Fig. 9). With this deposition break, the marine sandstone/shales facies is overlain by anhydrite facies or lagoon deposits.

In the studied area, the blocky sandstones facies reflects regressive or shallowing upward sequence. Based on the GR trend, the depositional environment of the Sidri blocky sandstone lithofacies can be interpreted as a marine dominant environment, most likely tidal sands channels (Emery and Myers 1996; Siddiqui et al. 2013; El-Tehiwy et al. 2019) (Table 4, Fig. 9). The interbedded sandstones facies reflects mixed regressive and transgressive sequences, where shallowing upward sandstones are intercalated with deepening upward shales and localized minor limestone streaks sequences. The interbedded sandstones with dominant shales and minor limestone facies typically reflect a low energy environment. Hence, mixed tidal flats and inter-fingering of clastics shelf with the marine environment likely represent the potential depositional environment for these successions (Emery and Myers 1996; Nazeer et al. 2016; Ashraf et al. 2019) (Table 3, Fig. 8). The shale deposits reflect transgressive or retrograding sequence, where shallowing upward sandstones intercalated with deepening upward shales and localized minor limestone streaks sequences. The shale deposits or finer facies have resulted from a transgressive sequence; however, the shape of GR of these deposits and the thickness of layers refer to stable conditions for a relatively short time. Based on the GR trend, the depositional environment is low relief offshore mudstone (Table 3, Fig. 8) (Emery and Myers 1996; Ashraf et al. 2019; Nazeer et al. 2016).

The middle Miocene Sidri sandstone displays increasing cumulative thickness within wells 1 and 3 , where the sandstone thicknesses in these wells reached maximum of 37 and $41 \mathrm{~m}$, respectively. This indicates that the sandstone reservoir of the middle Miocene Sidri displays local increasing thickness toward the northwest direction in the Badri field. However, the lithofacies of low relief offshore mudstone depositional setting cut this deposition direction and bounded the blocky sandstone facies of tidal sands channels depositional setting. The different depositional environments of the Sidri Member formed two sandstone lithofacies that differ in terms of thickness, grain size, sorting, and roundness. The blocky sandstone facies of tidal sands channels depositional setting of the middle Miocene Sidri Member tends to form thicker sandstone bodies, medium grain size, moderately to wellsorted grains, and sub-rounded grains. In contrast, the interbedded sandstone facies of mixed tidal flats depositional settings tends to have thin sandstone streaks, fine grain size, poor to moderately sorted grains, and sub-angular to sub-rounded grains. Therefore, the blocky sandstone facies of tidal sands channels of the middle Miocene Sidri Member possesses good reservoir potentiality than the interbedded sandstone facies of mixed tidal flats in the Badri field. In addition, the mud lithofacies of low relief offshore mudstone act as a lateral and bottom seal in the studied area at the level of the Sidri Member.

\section{CONCLUSIONS}

With the discussed integrated sedimentological, electrofacies, and depositional settings characteristics, it was demonstrated how the depositional system can be deducted using GR log with support of 
sedimentological analysis for geometry assessment of the middle Miocene Sidri sandstone reservoir during the Badri field development stage. The integrated work in this study is useful for assessment of reservoir distribution and quality, as well as for reduction of uncertainty during the field development. The key outcomes of this study are the following.

- The petrographic analysis of the middle Miocene Sidri Sandstones indicates arkosic sandstone with an average composition (i.e., samples Q70, F27, L3), sandstones are fine- to medium-grained with average of 312 microns, and the grains show moderate to well sorting in most samples; however, poorly sorted textures were recorded in some samples.

- Primary porosity is more dominant in the Sidri sandstones than the secondary one, which is formed by diagenesis of feldspars, and the measured total porosity averaged $13.8 \%$, while secondary porosity averaged $2 \%$ of total porosity. The Sidri sandstones are cemented by silica, while anhydrite and carbonate cementation is less abundant. Organic materials are visible as dark spots in some samples along with the Sidri sandstones intervals, which indicate oil-bearing or migration pathways.

- The facies analysis indicates that the studied member has a heterogeneous nature and rapid facies change; its main lithofacies are blocky sandstones, intercalated sandstones and shales, and shales.

- Three electrofacies were interpreted in the studied section, namely (1) electrofacies-A (blocky sandstones), which is characterized by a cylindrical-shaped (right boxcar) gamma-ray trend; (2) electrofacies-B (intercalated sandstones and shales), which is characterized by an irregular log trend with serrated shape; and (3) electrofacies-C (shales), which is characterized by irregular gamma-ray trend and has no character.

- The interpretations suggest tidal channel depositional settings for electrofacies-A (blocky sandstones), mixed tidal flat depositional settings for electrofacies-B (intercalated sandstones and shales), and low relief offshore mudstone depositional settings for electrofacies-C (shaly facies).
- The different depositional environments of the Sidri Member formed two sandstone lithofacies, which differ in terms of thickness, grain size, sorting, and roundness. The blocky sandstone tends to form thicker sandstone bodies, medium grain size, moderately to well-sorted grains, and sub-rounded grains. In contrast, the interbedded sandstone facies tends to have thin sandstone streaks, fine grain size, poor to moderately sorted grains, and sub-angular to sub-rounded grains.

- Therefore, the blocky sandstone facies of tidal sands channels of the middle Miocene Sidri Member possess good reservoir potentiality than the interbedded sandstone facies of mixed tidal flats in the Badri field. In addition, the mud lithofacies of low relief offshore mudstone acts as a lateral and bottom seal in the studied area at the level of the Sidri Member.

- This study demonstrates a fully integrated study of coupling petrographic characteristics and gamma-ray log patterns to interpret the depositional settings of the Serravallian Sidri Sandstones reservoir.

- This work can be useful for the assessment of reservoir geometry, distribution, and quality in hydrocarbon reservoirs that lacks conventional core samples. This work can also provide insights for reducing uncertainty during hydrocarbon field development in similar cases elsewhere.

\section{ACKNOWLEDGMENTS}

Great thanks to the two reviewers and Dr. John Carranza, Editor-in-Chief of Natural Resources Research, for their comments and suggestions, which greatly benefited the manuscript. I should refer to the fact that the Egyptian General Petroleum Corporation and Gulf of Suez Petroleum Company GUPCO authorities facilitated this research. Deep thanks for the Narodowa Agencja Wymiany Akademickiej (NAWA) under Project PPN/ULM/2019/1/00305/U/00001 for supporting this research as well as deep thanks to Prof. Alfred Uchman for his continuous support during the research period. Interpretations documented in this manuscript solely reflect those of the author and do 
not necessarily represent his respective organizations.

\section{OPEN ACCESS}

This article is licensed under a Creative Commons Attribution 4.0 International License, which permits use, sharing, adaptation, distribution and reproduction in any medium or format, as long as you give appropriate credit to the original author(s) and the source, provide a link to the Creative Commons licence, and indicate if changes were made. The images or other third party material in this article are included in the article's Creative Commons licence, unless indicated otherwise in a credit line to the material. If material is not included in the article's Creative Commons licence and your intended use is not permitted by statutory regulation or exceeds the permitted use, you will need to obtain permission directly from the copyright holder. To view a copy of this licence, visit http://creativecom mons.org/licenses/by/4.0/.

\section{REFERENCES}

Abudeif, A. M., Attia, M. M., Al-Khashab, H. M., \& Radwan, A. E. (2018). Hydrocarbon type detection using the synthetic logs: A case study, Baba member, Gulf of Suez, Egypt. Journal of African Earth Sciences, 144, 176-182.

Abudeif, A., Attia, M., \& Radwan, A. (2016a). New simulation technique to estimate the hydrocarbon type for the two untested members of Belayim Formation in the absence of pressure data, Badri Field, Gulf of Suez, Egypt. Arabian Journal of Geosciences, 9(3), 1-21.

Abudeif, A., Attia, M., \& Radwan, A. (2016b). Petrophysical and petrographic evaluation of Sidri Member of Belayim Formation, Badri field, Gulf of Suez, Egypt. Journal of African Earth Sciences, 115, 108-120.

Alsharhan, A. S. (2003). Petroleum geology and potential hydrocarbon plays in the Gulf of Suez rift basin, Egypt. AAPG Bulletin, 87(1), 143-180.

Ashraf, U., Zhu, P., Yasin, Q., Anees, A., Imraz, M., Mangi, H. N., et al. (2019). Classification of reservoir facies using well $\log$ and $3 \mathrm{D}$ seismic attributes for prospect evaluation and field development: A case study of Sawan gas field, Pakistan. Journal of Petroleum Science and Engineering, 175, 338-351.

Attia, M., Abudeif, A., \& Radwan, A. (2015). Petrophysical analysis and hydrocarbon potentialities of the untested Middle Miocene Sidri and Baba sandstone of Belayim Formation, Badri field, Gulf of Suez, Egypt. Journal of African Earth Sciences, 109, 120-130.

Baouche, R., Sen, S., Debiane, K., \& Ganguli, S. S. (2020). Integrated reservoir characterization of the Paleozoic and Mesozoic sandstones of the El Ouar field, Algeria. Journal of Petroleum Science and Engineering, 194, 107551.
Blum, P., Rabaute, A., Gaudon, P., \& Allan, J. F. (1997). Analysis of natural gamma-ray spectra obtained from sediment cores with the shipboard scintillation detector of the ocean drilling program: Example from leg 1561. In: Shipley, T. H., Y. Ogawa, P. Blum, \& J. M. Bahr (Eds.), Proceedings of the ocean drilling program, scientific results (p. 156).

Boggs, S. (1995). Principles of sedimentology and stratigraphy (p. 784). Toronto: Merrill Publishing Company.

Bosworth, W., Crevello, P., Winn, R. D., \& Steinmetz, J. (1998). Structure, sedimentation, and basin dynamics during rifting of the Gulf of Suez and north-western Red Sea. In Sedimentation and tectonics in rift basins red sea:-Gulf of Aden (pp. 77-96). Springer, Dordrecht.

Cant, D. (1992). Subsurface facies analysis. In R. G. Walker (Ed.), Facies models, response to sea level changes (pp. 27-45). St. John's: Geological Association of Canada.

Chow, J. J., Li, M. C., \& Fuh, S. C. (2005). Geophysical well log study on the paleoenvironment of the hydrocarbon producing zones in the Erchungchi Formation, Hsinyin, SW Taiwan. TAO: Terrestrial, Atmospheric and Oceanic Sciences, 16, 531545.

Díaz-Curiel, J., Miguel, M. J., Biosca, B., \& Medina, R. (2019). Environmental correction of gamma ray logs by geometrical/ empirical factors. Journal of Petroleum Science and Engineering, 173, 462-468.

Dolson, J. (2020). The petroleum geology of Egypt and history of exploration. In Z. Hamimi, A. El-Barkooky, J. Martínez Frías, H. Fritz, \& Y. Abd El-Rahman (Eds.), The geology of Egypt, Regional Geology Reviews. Cham: Springer.

Donselaar, M. E., \& Schmidt, J. M. (2005). Integration of outcrop and borehole image logs for high-resolution facies interpretation: Example from a fluvial fan in the Ebro Basin, Spain. Sedimentology, 52(5), 1021-1042.

Dott, R. H., Jr. (1964). Wacke, graywacke and matrix: What approach to immature sandstone classification? Journal of Sedimentary Research, 34(3), 625-632.

EGPC. (1996). Gulf of Suez oil fields (a comprehensive overview): Egyptian General Petroleum Corporation, Cairo (p. 736).

El-Ashry, M. T. (1972). Source and dispersal of reservoir sands in El Morgan field, gulf of Suez, Egypt. Sedimentary Geology, $8(4), 317-325$.

Ellis, D. V., \& Singer, J. M. (2007). Well logging for earth scientists (Vol. 692). Dordrecht: Springer.

El-Tehiwy, A. A., El-Anbaawy, M. I., \& Rashwan, N. H. (2019). Significance of core analysis and gamma-ray trends in depositional facies interpretation and reservoir evaluation of Cenomanian sequence, Alam El-Shawish East Oil Field, North Western Desert, Egypt. Journal of King Saud University-Science, 31(4), 1297-1310.

Emery, D., \& Myers, K. J. (1996). Sequence stratigraphy (p. 297). Hoboken: Blackwell Science Limited. https://doi.org/10.1002/ 9781444313710.

Farrell, K. M., Harris, W. B., Mallinson, D. J., Culver, S. J., Riggs, S. R., Wehmiller, J. F., et al. (2013). Graphic logging for interpreting process-generated stratigraphic sequences and aquifer/reservoir potential: With analog shelf to shoreface examples from the Atlantic Coastal Plain Province, USA. Journal of Sedimentary Research, 83(8), 723-745.

Garcia, M. N. (1981). Geophysical log correlation of far away logs drilled in the southern region of Mexico and its relation with the possible yucatan atoll (Spanish). Society of Petrophysicists and Well-Log Analysts.

Hughes, G. W., \& Beydoun, Z. R. (1992). The red sea-Gulf of Aden: Biostratigraphy, lithostratigraphy and palaeoenvironments. Journal of Petroleum Geology, 15, 135-156.

Kassem, A. A., Sharaf, L. M., Baghdady, A. R., \& El-Naby, A. A. (2020). Cenomanian/Turonian oceanic anoxic event 2 in October oil field, central Gulf of Suez, Egypt. Journal of 
African Earth Sciences, 165, 103817. https://doi.org/10.1016/j. jafrearsci.2020.103817.

Kessler, L. G., \& Sachs, S. D. (1995). Depositional setting and sequence stratigraphic implications of the Upper Sinemurian (Lower Jurassic) sandstone interval, North Celtic Sea/St George's Channel Basins, offshore Ireland. Geological Society, London, Special Publications, 93(1), 171-192.

Khalil, S. M., \& McClay, K. R. (2001). Tectonic evolution of the NW Red Sea-Gulf of Suez rift system. Geological Society, London, Special Publications, 187(1), 453-473.

Lyberis, N. (1988). Tectonic evolution of the Gulf of Suez and the Gulf of Aqaba. Tectonophysics, 153(1-4), 209-220.

Moustafa, A. R., \& Khalil, S. M. (2020). Structural Setting and Tectonic Evolution of the Gulf of Suez, NW Red Sea and Gulf of Aqaba Rift Systems. In The geology of Egypt (pp. 295-342). Springer, Cham.

Nabawy, B. S., \& Barakat, M. K. (2017). Formation evaluation using conventional and special core analyses: Belayim Formation as a case study, Gulf of Suez, Egypt. Arabian Journal of Geosciences, 10(2), 25.

Nabawy, B. S., \& El Sharawy, M. S. (2015). Hydrocarbon potential, structural setting and depositional environments of Hammam Faraun Member of the Belayim Formation, Southern Gulf of Suez, Egypt. Journal of African Earth Sciences, 112, 93-110.

Nazeer, A., Abbasi, S. A., \& Solangi, S. H. (2016). Sedimentary facies interpretation of Gamma Ray (GR) log as basic well logs in Central and Lower Indus Basin of Pakistan. Geodesy and Geodynamics, 7, 432-443.

Olayiwola, A. M., \& Bamford, K. M. (2019). Depositional environment and reservoir characterization of the deep offshore Upper Miocene to Early Pliocene Agbada Formation, Niger delta, Nigeria. Journal of African Earth Sciences, 159, 103578.

Patton, T. L., Moustafa, A. R., Nelson, R. A., \& Abdine, S. A. (1994). Tectonic evolution and structural setting of the Suez Rift: Chapter 1: Part I. Type Basin: Gulf of Suez.

Pirson, S. J. (1963). Handbook of well log analysis for oil and gas formation evaluation. Houston: Schlumberger Limited.

Posamentier, H. W., \& Allen, G. P. (1999). Siliciclastic sequence stratigraphy: concepts and applications (Vol. 7, p. 210). Tulsa, Oklahoma: SEPM (Society for Sedimentary Geology).

Radwan, A. E., (2014). Petrophysical evaluation for Sidri and Baba members within Belayim Formation in the region of Badri field, Gulf of Suez, Egypt. M.Sc. Thesis https://doi.org/ 10.13140/rg.2.2.22772.09601.

Radwan, A. E., (2018). New petrophysical approach and study of the pore pressure and formation damage in Badri, Morgan and Sidki fields, Gulf of Suez Region Egypt: PhD Thesis. h ttps://doi.org/10.13140/rg.2.2.26651.82727.

Radwan, A. E., (2020a). Wellbore stability analysis and pore pressure study in Badri field using limited data, Gulf of Suez, Egypt: AAPG/Datapages Search and Discovery Article \#20476 (2020). https://doi.org/10.1306/20476radwan2020.

Radwan, A. E., (2020b). Hydrocarbon Type Estimation Using the Synthetic Logs: A Case Study in Baba Member, Gulf of Suez, Egypt: AAPG/Datapages Search and Discovery Article \#20475 (2020). https://doi.org/10.1306/20475radwan2020.

Radwan, A. E. (2020c). Effect of Clay Minerals in Oil and Gas Formation Damage Problems and Production Decline: A Case Study, Gulf of Suez, Egypt: AAPG/Datapages Search and Discovery Article \#20477 (2020). https://doi.org/10.1306/ 20477radwan2020.

Radwan, A. E., Abudeif, A. M., \& Attia, M. M. (2020a). Investigative petrophysical fingerprint technique using conventional and synthetic logs in siliciclastic reservoirs: A case study, Gulf of Suez basin, Egypt. Journal of African Earth Sciences, 167, 103868. https://doi.org/10.1016/j.jafrearsci.2020. 103868 .
Radwan, A. E., Abudeif, A. M., Attia, M. M., Elkhawaga, M. A., Abdelghany, W. K., \& Kasem, A. A. (2020b). Geopressure evaluation using integrated basin modelling, well-logging and reservoir data analysis in the northern part of the Badri oil field, Gulf of Suez, Egypt. Journal of African Earth Sciences, 162, 103743. https://doi.org/10.1016/j.jafrearsci.2019.103743.

Radwan, A. E., Abudeif, A. M., Attia, M. M., \& Mahmoud, M. (2019a). Development of Formation damage diagnosis workflow, application on Hammam Faraun reservoir: a case study, G.O.S, Egypt. Journal of African Earth Sciences, 153, 42-53. https://doi.org/10.1016/j.jafrearsci.2019.02.012.

Radwan, A. E., Abudeif, A., Attia, M., \& Mahmoud, M., (2019c). Formation damage diagnosis, application on hammam faraun reservoir: A Case Study, Gulf of Suez, Egypt. In Offshore Mediterranean conference. https://doi.org/10.13140/rg.2.2.223 52.66569.

Radwan, A. E., Abudeif, A., Attia, M., \& Mahmoud, M., (2019d). Development of formation damage diagnosis workflow, application on Hammam Faraun reservoir: A case study, Gulf of Suez, Egypt. In Offshore Mediterranean Conference. ISBN9788894043679-2019.

Radwan, A. E., Abudeif, A. M., Attia, M. M., \& Mohammed, M. A. (2019b). Pore and fracture pressure modeling using direct and indirect methods in Badri Field, G.O.S, Egypt. Journal of African Earth Sciences, 156, 133-143. https://doi.org/10.1016/ j.jafrearsci.2019.04.015.

Radwan, A. E., Kassem, A. A., \& Kassem, A. (2020c). Radwany Formation: A new formation name for the Early-Middle Eocene carbonate sediments of the offshore October oil field, Gulf of Suez: Contribution to the Eocene sediments in Egypt. Marine and Petroleum Geology, 116, 104304. https://doi.org/ 10.1016/j.marpetgeo.2020.104304

Radwan, A., \& Sen, S. (2020). Stress Path Analysis for Characterization of In Situ Stress State and Effect of Reservoir Depletion on Present-Day Stress Magnitudes: Reservoir Geomechanical Modeling in the Gulf of Suez Rift Basin, Egypt. Natural Resources Research. https://doi.org/10.1007/s 11053-020-09731-2.

Radwan, A. E., Trippetta, F., Kassem, A. A., \& Kania, M. (2020d). Multi-scale characterization of unconventional tight carbonate reservoir: Insights from October oil filed, Gulf of Suez rift basin, Egypt. Journal of Petroleum Science and Engineering. https://doi.org/10.1016/j.petrol.2020.107968.

Rider, M. H. (1990). Gamma-ray log shape used as a facies indicator: critical analysis of an oversimplified methodology. In Geological Society, London, Special Publications (pp. 2737). https://doi.org/10.1144/GSL.SP.1990.048.01.04.

Robson, D. A. (1971). The structure of the Gulf of Suez (Clysmic) rift, with special reference to the eastern side. Journal of the Geological Society, 127(3), 247-271. https://doi.org/10.1144/g sjgs.127.3.0247.

Saggaf, M. M, \& Nebrija, E. L. (1999). Estimation of lithofacies and depositional facies from wireline logs, MIT Borehole Acoustics and Logging/Reservoir Delineation Consortia, Annual Report, 2-1-2-24.

Salah, M. G., \& Alsharhan, A. S. (1997). The Miocene Kareem Formation in the southern Gulf of Suez, Egypt: A review of stratigraphy and petroleum geology. Journal of Petroleum Geology, 20(3), 327-346.

Selley, R. C. (1978). Concepts and methods of subsurface facies analysis: American Association of Petroleum Geologists Contin Educ Course Notes Ser: 9-82.

Serra, O. (Ed.), (1989). Sedimentary environments from wireline logs, Schlumberger Educational Services.

Siddiqui, N. A., El-Ghali, M. A., Bin Abd Rahman, A. H., Mijinyawa, A., \& Ben-Awuah, J. (2013). Depositional environment of shallow-marine Sandstones from outcrop gamma-ray logs, Belait Formation, Meragang Beach, Brunei Darus- 
salam. Research Journal of Environmental and Earth Sciences, 5(6), 305-324.

Skupio, R., Kubik, B., \& Wolański, K. (2019). Archival gamma ray logs standardization by nondestructive core measurements of the low-radioactivity rocks. Acta Geophysica, 67, $1835-1844$.
Tucker, P. (1981). Palaeointensities from sediments: Normalization by laboratory redepositions. Earth and Planetary Science Letters, 56, 398-404.

Wagoner, J. C., Mitchum, R. M., Campion, K. M., \& Rahmanian, V. D. (1990). Siliciclastic sequence stratigraphy in well logs, cores, and outcrops: concepts for high-resolution correlation of time and facies. III-55. 